\title{
GRHPR Gene
}

National Cancer Institute

\section{Source}

National Cancer Institute. GRHPR Gene. NCI Thesaurus. Code C148626.

This gene is involved in the metabolism of glyoxylate and hydroxypyruvate. 